Environment Conservation Journal 15(1 \& 2)77-82, 2014

ISSN 0972-3099 (Print) 2278-5124 (Online)

Abstracted and Indexed

\title{
Effect of wildlife damage on the life of people living around Kaziranga National Park
}

\section{Daisy Das}

Received:21.11.2013

\author{
Revised: 02.04.2014
}

Accepted:28.04.2014

\begin{abstract}
The benefit from protected area is enjoyed at international level where as benefit is negligible at local level and often people have to bear losses for living around protected area. Wildlife damage is one such cost of living around protected area. Wild animals often destroys crop, assets, kill livestock and destroy property. Such wildlife damage many times becomes a bone of contention between people living around protected area and the park authority. In developing countries it becomes difficult to control such damage for park authority and giving compensation is not a feasible way. Therefore, the present study tries to assess the extent of wildlife damage in Kaziranga National Park (KNP) which is conflict ridden. It has been found from the survey that damage is enormous and people are dissatisfied with the park authority. This paper suggests that to obtain support of local people emphasis should be given crop protection measures and alternative livelihood opportunities.
\end{abstract}

Keywords: EDC, logistic regression, Kaziranga, park people relation, protected area, wildlife damage

\section{Introduction}

The conflict regarding the use of natural resource and the rights to land around protected area have received attention worldwide in recent years (Mukherjee, 2009). It has been observed that the indigenous people lose right to forest resources with declaration of protected area. Therefore, there is often conflict. Besides deprivation there is wild life damage for which they have never been compensated. This resulted in hostility to the park and the park authority often had to face the wrath of local people in the form of encroachment, poaching and wildlife habitat alteration caused by agricultural expansion and excessive collection of forest products. All these factors have led to park people conflicts which undermine long-term biodiversity conservation efforts (Castro and Nielson, 2001). Many times conflict become severe and debilitating resulting in violence, resource degradation, the undermining of livelihoods and the uprooting of communities. Sometimes it may be sufficient to destroy the original structure of the society (Suliman, 1999). Human animal conflict is topic of major local political concern and a problem for conservationist (Hoare, 1999, 2000).

\section{Author's Address}

Department of Economics, North Eastern Hill University

Shillong, Meghalaya

Email: daisy.das@gmail.com
Normally a person living near the boundary has to bear loss disproportionately due to crop raiding mainly when portended area is situated within agricultural landscape. Mackenzie (2012) has evaluated financial and social costs associated with crop raiding around Kibale National Park, Uganda. Perceptions about crop raiding were collected using focus groups and household surveys, while damage was evaluated based on physical monitoring of crop raiding incidents. The loss was found to be more within $.5 \mathrm{~km}$ of the park boundary. As a result they were suffering from food insecurity. Compensation is not affordable for the wildlife authority, nor is it sustainable as crop raiding is escalating. To mitigate costs for local communities, funding has been justified for mitigating crop raiding. Ogra (2008) finds that Human-wildlife conflict (HWC) is a growing problem for communities located at the borders of protected areas. Such conflict commonly takes place as crop raiding events and as attack by wild animals, among other forms. The research also showed that although women in the study area bore a disproportionate burden of these effects, roughly half of survey respondents perceived that men and women were equally affected. A possible explanation for this gap considers the relationships between gendered uses of space, work, status, and identity. One common

All rights of reproduction in any form reserved 
cost of living around protected area is the loss of livestock caused by predator (Holmerna, 2007). All these require crop protection measures and electric fencing is very effective in preventing wildlife damage (Thapa, 2010). Pereza and Pacheco (2006) propose that conservation efforts, should consider both applying methods to reduce wildlife damage and provide direct or indirect economic compensation. Therefore, the presents study aims to assess the extent of wildlife damage and examine if such wildlife damage affect the park people relation around protected area.

\section{Material and Methods}

Kaziranga National Park (KNP) is known all over the world for its rich biodiversity and getting the top priority as tourist destination. It is divided as the Central, Eastern, and Western sectors consisting semi evergreen forested highland, rivulets, marshes and extensive plains. While reviewing conservation history it has been found that after Lady Curzon visited KNP in 1905, the park was declared Kaziranga as reserved forests in 1908. Now KNP is a World Natural Heritage Site and a name known worldwide for its success in the conservation history of one horned Indian Rhinoceros, provides habitat for a number of threatened species and migratory birds. Initially the park had an area of 430 sq. km. But six additions have been made at different times increasing the total area of the park to $859.42 \mathrm{~km}^{2}$. The main purpose behind adding these areas were to create corridor and buffer zone for safety of the animals. Unfortunately, only two areas have been taken over by the park authority legally. The people around the park are enjoying benefits as well costs of protection. In 2006-2007, the total amount of money that flowed through the tourism sector in Kaziranga National Park was estimated to be 5 million dollar per annum (Hussain et al. 2012). It is also assumed that people around the park are also enjoying the benefits from welfare measures introduced by the park authority and also from the eco development measures. The park authority has been administering different programs for the welfare of the people around the park. They include animal vaccination programs with the help of World Wildlife Fund, providing facility of safe drinking water, provision of community hall, schools and provision of health centres. To reduce the forest dependence, eco-development programs was introduced in 2008. The main purposes of these schemes are to provide livelihood by some other schemes mostly related to tourism and self employment. In spite of all such measures the park people relation is often resented (Mathur and Mishra, 2005, Shrivastava and Haenin, 2007). At the same time it has also been suffering from deprivation and cost of wildlife damage (Di Fonzo, 2007). There is frequent animal raiding of crops and sometimes human life is also lost. The study mainly uses primary data collected by sample survey conducted at household level. To select samples two stage sampling have been used. In the first stage, 10 villages have been selected randomly which are situated on the boundary of the park at different distances from the core zone of the park. The study does not involve the addition areas where people are still residing despite prohibition. Legally this area belongs to the park and the authority is not responsible for the welfare of the people living in this area. In the second stage a total of 205 sample sizes have been surveyed with the help of random sampling. Required information has been collected with the help of a semi structured questionnaire which took almost 1 to1.5 hours on an average to be completed. The questionnaire comprises questions on demographic and socio economic condition, resource extraction from the park as well as on items of costs and benefit of living around KNP. The field work was conducted from September 2012 to January 2013. To analyze the data ANOVA, ' $t$ ' test, Chi square test and logistic regression have been used.

\section{Results and Discussion \\ Demographic and socio economic characteristics of respondents}

It has been found from the field survey that the majority of the respondents belong to other backward caste (39 percent) followed by scheduled tribe (30.2 percent), general caste (19 percent) and scheduled caste (11.7 percent) people. This difference in caste has been found to be statistically significant at $\chi^{2}=35.80(3)<0.00$. It has been found from the survey that almost 42.5 percent of the respondents are farmers out of which 15 percent earn subsidiary income from tourism also. This is followed by labourers in the tea garden or 
agriculture (21.5 percent). Almost 20.20 percent are directly related to tourism related business activities followed by servicemen ( 9.8 percent including jobs in tourism sector) and 6 percent were involved in other activities. This difference in occupation has also been found to be statistically significant at $\chi^{2}=100.31(5)<0.01$ The average family income per month is Rs.4001.00 and the average size of land holding is 19.69 hectare. The size of land holding is not so small but 45 percent of the respondents do not use land for growing paddy. The land is fertile but people prefer home gardens. Besides, 88 percent of the respondents are affected by flood also and wildlife damage is a problem which is very common in the life of the villagers living around KNP. The wildlife damage has been found to be rampant (Table 1) around the park. Almost 22 percent of the respondents have been suffering from damage of dwelling houses. Farming is the occupation of the majority of the people but most of the time crop is damaged either wild animals or flood (28.8 percent). It has been reported informally that besides wild animals many times flock of birds like parrots or monkeys come from the park and destroy crop. There are 26.3 percent respondents who have to bear the loss both from the destruction of houses as well as crop. Thus, altogether 77.6 percent of the respondents have been found to have suffered from some or the other kind of wildlife damage in the last couple of years. It is clear from Table 2 that respondents practicing paddy cultivation suffer more from wildlife damage. The relation between types of cultivation and amount of animal damage has been found to be statistically significant $\quad\left(\mathrm{F}_{78,126}=2.145<.001\right)$. Therefore, to avoid such loss people may prefer home garden to paddy cultivation. Is been found from table 3 that wildlife damage is the highest in the nearest villages to the park (Mackenzie, 2012). But damage does not decline monotonically with increase in distance from the park. As one moves away from core zone the amount of damage initially declines but again increases with the increase in distance from the core zone. This shows that there is association between distance from the core zone and the amount of wildlife damage (Rao et al., 2002). But people hardly receive any compensation for such damage. The process of claiming compensation is a complicated process which needs a picture of the wild animals while destroying crops. Many times it is difficult and people avoid it. Besides, giving compensation to everyone affected by wildlife damage is not a feasible option (Mackenzie and Ahabyona, 2012). Therefore, emphasis should be given crop protection measures. The yearly mean value of damage is Rs. 4694.69 and the mean value of property damage and crop damage are Rs.3500.00 and Rs.4436.68 respectively. But the mean value of damage is the highest (Rs. 9984.22) for those who suffer from combination of damages i.e. the damage of property and damage of crop or paddy. This difference in mean value damage has been found to statistically significant $\left(\mathrm{F}_{78}=6.486\right.$, $p=.001)$. Taking into consideration the problem of animal raiding, it is really important to implement measures for crop protection. Initiative was taken in 2008 to install fence to ensure crop protection as part of a Rapid Action Project implemented by the Assam Forest Department, local EDC and Wildlife Trust of India (WTI), with the support of Asian Adventures and International Fund for Animal Welfare (IFAW). The fences run by electricity and solar energy was limited to few villages. But these are often damaged by flood and there is lack of maintenance. It has been found from the survey that only 11.7 percent of the respondents have crop protection committee in their locality out of which more than half is formed by the initiative of local youths without any support of the park authority or any other organization. There is always conflict between park authority and people living around and people have negative attitude towards parks (Shyamsundar and Kramer 1997; Gillingham and Lee 1999). To understand the park people relation respondents were asked what they felt about their relationship with the park authority. It has been found from the survey that 88 percent of the respondents feel that the relation between park and the people is bitter. Their grudge is apparent from their responses. Therefore, it has been tried to find the factors behind it. Taking into consideration the present scenario, the paper takes into consideration the following reasons: whether they earn anything from tourism activities (income_tourism), presence of eco development committee (presence_EDC), presence or absence of crop protection committee (committee_crop), wildlife damage (wildlife_ 
Table 1: Types of animal damage

\begin{tabular}{|l|l|}
\hline Types of damage & Percentage of respondents suffering wildlife damage \\
\hline Do not suffer from wildlife damage & 22.4 \\
\hline Home damage & 22.0 \\
\hline Crop damage & 28.8 \\
\hline Livestock killed by wild animals & .5 \\
\hline Both house and crop damage & 26.3 \\
\hline
\end{tabular}

Table 2: Wildlife damage caused to those practicing agriculture and home garden farming

\begin{tabular}{|l|l|l|l|l|l|l|}
\hline $\begin{array}{l}\text { Production } \\
\text { type }\end{array}$ & $\begin{array}{l}\text { No such } \\
\text { wildlife damage }\end{array}$ & $\begin{array}{l}\text { Home } \\
\text { damage }\end{array}$ & $\begin{array}{l}\text { Crop } \\
\text { damage }\end{array}$ & $\begin{array}{l}\text { Livestock } \\
\text { damage }\end{array}$ & $\begin{array}{l}\text { Both house and } \\
\text { crop damage }\end{array}$ & Total \\
\hline Agriculture & 8 & 4 & 58 & 0 & 42 & 112 \\
\hline Home garden & 38 & 41 & 1 & 1 & 12 & 93 \\
\hline Total & 46 & 45 & 59 & 1 & 54 & 205 \\
\hline
\end{tabular}

Table 3: Mean value of wildlife damage at different distance from the core zone of KNP

\begin{tabular}{|l|l|l|}
\hline Distance_from_KNP & Mean (in Rupee) & Std. Deviation \\
\hline Less than 1 km & 6653.82 & 9430.611 \\
\hline More than 1 km & 2846.41 & 4083.427 \\
\hline $2 \mathrm{~km}$ and more & 4424.34 & 5559.403 \\
\hline Mean value of damage & 4694.69 & 6713.956 \\
\hline
\end{tabular}

Table 4: Results of logistic Regression

\begin{tabular}{|l|l|l|l|}
\hline Variables & $\mathbf{B}$ & Sig. & $\mathbf{E x p}(\mathbf{B})$ \\
\hline Income_tourism & .731 & .337 & 2.077 \\
\hline Presence_EDC & 2.391 & .074 & 10.927 \\
\hline Committee_crop & -18.007 & .998 & .000 \\
\hline Wildlife_damage & 1.275 & .006 & .279 \\
\hline Compensation_received & .586 & .630 & 1.797 \\
\hline
\end{tabular}

Source: Calculated by the author from the field survey 
damage) and whether they receive compensation from such damage or not(compensation_received). Since the dependent variable is binary in nature a logistic regression has been applied to find the significant independent variable which affect the park people relaitonship.It has been found from the logistic analysis conducted by using SPSS 16 that the value of the Wald statistics is $88.271(\mathrm{p}<0.01)$ and Nagelkerke R square is .266 along with a value of Cox and Snell R square equal to .100. The Cox and Snell $\mathrm{R}$ square should be less than 1 and the result satisfies the condition. The Nagelkerke $R$ square indicates a moderate relationship of 26.6 between predictors and prediction (IDRE, 2014, Wuensch, 2014, Anonymous, 2014). The Wald value shows that the overall fit of the model is good. It has been found from table 4 that income from tourism is not a significant factor to affect the park people relationship. It has been found from the survey that almost 35 percent people are directly or indirectly are related to tourism activities and the income from tourism is not so high annually (Rs.5666.67). But presence or absence of EDC is a significant variable and a respondent from villages without EDC is 10.927 times more likely to have a bitter feeling against the park. The next significant variable is wildlife damage. It has been found that a respondent suffering from wildlife damage is .279 times more likely to have bitter feelings towards the park in comparison to a respondent who do not experience wildlife damage. There is a provision of compensation for wild animal damage but only 6.8 percent respondents have received compensation in the last few years. The villagers have reported that the claim process is complicated where they have to submit a photograph of the spot during destruction. The villagers often fail to do and suffer from monetary loss caused by animal depredation. Wildlife damage may make people's income fall to subsistence level. Against such regular uncompensated wildlife damage the welfare enjoyed by the villagers rendered by the park authority is also nominal. From the survey it has been found that 76.1 percent of the respondents have not received any welfare measures provided by the park authority. Under such a situation people may become hostile to the park. Therefore, people should be provided other sustainable livelihood opportunities at local level. The eco development committee should be newly constructed and their role should be strengthened. Simultaneously, there should be policy initiative which gives boost to both mass tourism and ecotourism activities.

\section{Conclusion}

This study is a clear manifestation of the fact that wildlife damage is fair enough to cause discontent among the people living in the surrounding area of KNP. There is provision for compensation measure but it is neither sufficient nor efficient. Moreover, the idea of giving compensation to everyone affected by wildlife damage is not a feasible option especially in a developing country (Mackenzie and Ahabyona, 2012). Therefore, the alternative solution lies in implementing crop protection measures. Besides, any policy of sustainable protected area management should evolve around the issue of sustainable livelihood to ensure that loss of agricultural output due to wildlife damage do not push people below poverty line. This will induce people to believe that their survival depends on the existence of KNP and people will become more conservation oriented. Effort to conserve protected area may go in vain if problem of the periphery area caused by wildlife is not taken into consideration.

\section{Acknowledgement}

The author is thankful to University Grant Commission, Government of India for the financial support for the research project entitled "Costs and Benefit of Protection: A Case Study of Kaziranga National Park in the 2012. The paper is part of the project work.

\section{References}

Castro A. P. and Nielson, E. 2001. Indigenous people and comanagement: implications for conflict management, Environmental Science \& Policy, 4:52-59

Di Fonzo, M. M. I. 2007. Determining correlates of humanelephant conflict reports within fringe villages of Kaziranga National Park, Assam. Master's thesis of university of London. Available at www.iccs.org.uk.

Gillingham. S. and Lee, P.C. 1999. The impact of wildliferelated benefits on the conservation attitude of local people around the Selous Game Reserve, Tanzania. Environ Conserv, 26(3), 218-228 
Hoare, R.1999. Determinants of human-elephant conflict in a land-use mosaic, Journal of Applied Ecology 36 (5): 689-700.

Hoare, R. 2000. African elephants and humans in conflict: the outlook for coexistence, Oryx,34 (1): 34-38.

Holmerna,T., Nyahongoa, J. and Røskafta, E. 2007. Livestock loss caused by predators outside the Serengeti National Park, Tanzania, Biological Conservation, 135: 518 -526

Hussain, S.A., Barthwal, S.C.,Badola, R., Rahman, S.M.T., Rastogi, A., Tuboi,C. and Bhardwaj, A.K. 2012. An analysis of livelihood linkages of tourism in Kaziranga national park, a natural world heritage site in India, Parks, 18(2): 32-43

IDRE, 2014. Institute for Digital Research And Education available at www.ats.ucla.edu

Mackenzie, C. A. 2012. Accruing benefit or loss from a protected area: Location matters, Ecological Economics, 76: 119-129.

Mackenzie, C.A. and Ahabyona, P. 2012. Elephants in the garden: Financial and social costs of crop raiding, Ecological Economics, 75: 72-82.

Mathur V.B. and Mishra, M. 2005. UNESCO-IUCN Enhancing our heritage project: Monitoring and manageing for success in natural world heritage sites. Technical Report No. 04, IUCN

Mukherjee, A. 2009. Conflict and Coexistence in a National Park, Economic \& Political Weekly, XLIV, 23:52-59
Ogra, M. V. 2008. Human-wildlife conflict and gender in protected area borderlands: A case study of costs, perceptions, and vulnerabilities from Uttarakhand (Uttaranchal), India,Geoforum, 39: 1408-1422

Pe'reza, E.1, Pacheco, L. F. 2006. Damage by large mammals to subsistence crops within a protected area in a montane forest of Bolivia, Crop Protection, 25 :933-939

Rao, K.S., Maikhuri, R.K., Nautiyal, S., Saxena, G. 2002.Crop damage and livestock depredation by wildlife: a case study from Nanda Devi Biosphere Reserve, India, Journal of Environmental Management, 66(3):317-327

Shrivastava, R. J. and Heinen, J. 2007. Implications for conservation and development planning: a microsite analysis of resource use around Kaziranga National Park, The Journal of Environment Development. 16:207-226.

Shyamsundar, P. and Krammer, R. 1997. Biodiversity conservation-At what cost? A study of households in the vicinity of Madagaskar's Mantadia National Park, Ambio, 26(3):180-184.

Suliman, M. 1999. Ecology, Politics \& Violent Conflicts, Zed, London.

Thapa, S. 2010. Effectiveness of crop protection methods against wildlife damage: A case study of two villages at Bardia National Park, Nepal, Crop Protection, 29: 12971304

Wuensch, K. L. 2014. Binary Logistic Regression with SPSS. Available at http://core.ecu.edu/ 